\title{
The Effects of Ship Loading Cost (General Cargo), Unit Ship's Call And Ship's Gross Tonnage Towards Non-Migas (Oil And Gas) Exports, With Four Destination Countries To U.S.A, Japan, Australia, And United Kingdom At Port Of Surabaya, Indonesia In 2014-2016
}

\author{
Murpin Josua Sembiring \\ Widya Kartika University \\ Herman Budi Sasono \\ Widya Kartika University
}

\begin{abstract}
The importance of international trade in the development of Indonesia economy which will increase the export role especially in non-oil and gas export. However, the export activities have to be supported by the availability of ships since the shipping facilities having a very important role in the sea transport system. This research was conducted with the aim to analyze the influence of Ship Loading Costral Cargo), Unit ship call, and Ship's Gross Tonnage on Non-Oil and Gas Export Destination Countries to U.S.A, Japan, Australian, and U.K at Port of Surabaya Indonesia Year 2014 - 2016. This research used quantitative approach, with secondary data engineering as data collection. The data analysis techniques which used is SEM analysis using PLS. The results in this paper reveals that (1) Ship Loading Cost (General Cargo) has a significant influence on Non-Oil and Gas Exports, (2) Unit Ship Call has no significant influence on Non-Migas (Oil and Gas) Exports (3) Gross Tonnage is insignificant to Non Oil and Gas Exports.
\end{abstract}

Keywords: General Cargo, Unit Ship's Call, Ship's Gross Tonnage, Non-Migas (Oil and Gas) Export

\section{INTRODUCTION}

In the Indonesia's economy, International trade is one of several factors which give influences and plays an important role for the sustainability in the economy of Indonesia. The role of international trade is crucial for many countries, especially in developing countries which depends on export, primarily as the primary commodities, to gain foreign exchange in an effort to increase domestic savings as well as paying off foreign debt which tends to increase every year (Todaro, 2000).

The existence of international trade can provide some benefits, one of them is able to provide employment. The increase of exports both in amount and type of goods or services always strived by various strategies such as the exports development, especially in non-oil and gas exports, both goods and services. It aims to support the role of exports in an effort to improve the global competitiveness of Indonesia's products and increase the role of exports in spurring economic growth.

Export is a process of trade between two countries, where one of them take the role as a seller and one as a buyer. The seller is called the exporter and the buyer is the importer. Export itself is one of the foreign exchange contributors to the state and as a tool of financing for the development of a country. Foreign exchange should move positively with development, where 
the higher level of development, then, the owned foreign exchange should increase in order to maintain the stability of the national economy. Export activities still going to occupy an important role as a driver of the domestic economy. Therefore, the direction of policy in the field of export trade is intended to increase the goods export especially in non-migas (oil and gas) commodites.

Non-migas (oil and gas) exports as an international trading activity needs to be supported by Interinsular vessels both Liner boats, Tramper ships, and Special Shipping vessels, either with national flags as well with foreign flagged flags which become liaison from one to another island in order to ensure the smooth flow of goods. In this case, ships as a means of services have a very important role in the sea transport system. Almost all imported of goods, exports and large quantities of cargo transported by ship. This is considering the vessel has a much larger capacity than other means of transport. In this case, the ship's arrival rate or ship's call will be able to affect the existing exports. Sasono (2017) explains that the arrival of the ship or Ship's call is the flow of the incoming and leaning ships to a port for loading and unloading of goods and loading and unloading of passengers per period. Moreover, the loading cost of the vessel may also have an impact towards the smooth flow of export activities.

Based on the previous background description, this research is conducted with the aim to analyze the effect of Ship loading cost (General Cargo), Unit Ship Call, and Ship's Gross Tonnage on Non-Oil and Gas Exports Destination to U.S.A, Japan, Australia, and U.K at Port of SurabayaIndonesia 2014-2016.

\section{REFERENCE REVIEWS}

The Research of Economies of scale in large containerships, performed by Cullinane, K., \& Khanna, M. (2000), explains that the improvement of the operation of large Container ships can improve the economy of a county. The research on full cost recovery in EU Ports Operating was conducted by Gardner (2006), he stated, that, this study compared at three EU ports which recommend on full costing of port services may result in the increase of export costs. Research on the economic impact from cruise ship visits in Australia was conducted by Dwyer, L., Douglas, N., \& Livaic, Z. (2004), who stated that the international shipping industry has consistently increased the average annual growth of $8.4 \%$ in 1980 . While the domestic market had increase of 50,000 Australians who made the voyage annually. Research on port management and loading and unloading performance in Taiwan container port was done by $\mathrm{Yu}, \mathrm{MM}, \mathrm{Hsiao}, \mathrm{B} ., \mathrm{Hsu}, \mathrm{SH}, \& \mathrm{Li}, \mathrm{SY}$ (2012), this study presents an alternative approach to evaluate the efficiency and overall performance of Taiwan container port. The results showed, implementation on the multi-activity network DEA model (MNDEA) can effectively demonstrate improvements to resources, as well as increase the output and more perfect improvements. The results of this study also indicate the direction of improvement occurred at the efficiency of the port.

\section{General Cargo}

General Cargo Ship is a ship carrying a variety kind of cargo goods. The transported goods usually are the goods that have been packed. The Ship of General Cargo is equipped with a cargo carrier to ease the loading and unloading activities (Manik et al, 2013).

Stevedoring is the work of unloading goods from ships. According to Suyono (2005: 310), Stevedoring is a job to unload goods from ships to the dock/barge of the truck or loading goods from the dock/barge/truck into the ship until it is arranged in the hatch of the ship using a ship's tow or a land crane. Stevedoring activity does not include other activities, such as:

a. Shifting is the activity of moving the load in a different hatch or by land. 
b. Lashing / unlashing is binding / strengthen the loads or vice versa to release the cargo's amplifier or knot

c. Dunning is to install the tools or loads separator

Studies conducted by Sánchez, R. J., Hoffmann, J., Micco, A., Pizzolitto, G. V., Sgut, M., \& Wilmsmeier, G. (2003). It was about port efficiency and freight costs, it stated that most of the changes in port's transportation costs are critical to port efficiency by the PCA method. The result of the research shows that there is a significant influence of the availability of port service, distance, and goods value per ton towards loading and unloading cost. Park, C. S., \& Noh, Y. D. (1987) conducted research on Cargo management at the port in Labama, the improved port capacity are capable of giving a positive effect on the increase of income. Kozan, E. (2000). The use of container ships has reduced the cost of loading and unloading operations in ports, thereby increasing the efficiency and speed of transportation. This is done to reduce the cost of maritime transport, especially by reducing cargo costs, and ship's duration at ports by accelerating handling operations. This paper discusses the main factors which affect the efficiency of container terminal transfers. The network model is designed to analyze the progress of container systems and applied to the port container terminal. The model which presented here can be seen as a decision support system in the context of the assessment of container terminal investment.

\section{Unit Ship's Call}

The arrival of the ship or Ship's Call is the current of the ship that enters and lean to a port to unload the goods and passenger loading and unloading per period, such as Ship's Call per day or Ship's Call per month or per year (Sasono, 201T). Unit Ship's Call is the arrival of ships coming into the port viewed from the side per unit or per ships. The flow of ships entering the port is the same as the ships left from the port, therefore, commonly the data which recorded by Port Master or by Port Administration is the incoming ship flow (Ship's Call), since this number is automaticaly already represent of the current ship who ought to left the port, unless there is a sinking or burning ship beside the pier in addition due to Stevedore technical error which show how unprofessional in maintaining the balance of the ship crossing and longitudinal ship balance while doing load and unloading goods from or to the ship, thus, it will automatically arise a difference between the flow of incoming ships and the outflow of ships port (Sasono, 2017).

Vacca, I., Bierlaire, M., \& Salani, M. (2007). Have conducted research of Optimization at container terminals: status, trends, and perspectives. By declaring the timing of the vessel turnover can reduce the cost levels incurred by the shipping agency and able to perform the efficiency of loading and unloading costs as well as the stacking field which impacting on improved performance. Bendall, H. B., \& Stent, A. F. (2001), conducted a study of a scheduling model for a high-speed containership service. The results of this study prove that the increase of investment in port's technology will affect the speed of ships service, the frequency of service, as well as the transportation tariff, and the container volume so that the velocity of the ship can be faster and efficient.

\section{Gross Tonnage Ship}

The results of Blonigen, B. A., \& Wilson, W. W.'s (2008) research, stated that international trade is highly influenced by the completeness of port facilities, as well as the speed of loading and unloading ships greatly affect the cost efficiency of imports in America. Further, Miller, F. (2011) stated that climate change can cause the decreasing of basin's depth which impacts on 
decreasing draft of the ship, thus affecting the movement of Cargo ship and increasing Cargo shifting cost. The research from Silberholz, M. B., Golden, B. L., \& Baker, E. K. (1991), stating operational loading and unloading container in the port is crucial to improve work productivity in order to create work efficiency and cost of ship loading. Tangzon J.L (2009) conducted a study of factors affect the selection of ports for export activities in Southeast Asia including port selection, port operator policy and customs, from the results of this study, it found the factors which affecting the decision of harbor selection is an efficiency factor. According to Mangan, J., Lalwani, C., \& Fynes, B. (2008), they argued that ports can play a strategic role in supporting the supply chain that is not limited to transshipment points alone.

According to the Regulation of the Minister of Transportation Number: KM 6 Year 2005, on Measurement of ships, the ship's tonnage is the volume of vessels expressed in Gross Tonnage (GT) and net tonnage (NT), while ship's Gross Tonnage represents volume or the contents of a ship reduced by the contents of a certain number of rooms that serve as a vessel for the security of the ship's exemption spaces.

According to the Regulation from the Head of Area of Free Trade Zone and Batam-Free Port No. 17 in 2016, about guidance of type and service rates at the Port Office of the Free Port and Free Trade Zone of Batam, Gross Tonnage (GT) ship is the volume calculation of all room located under the deck, plus with the volume of enclosed spaces located above the deck, plus with the contents of the room and all the enclosed rooms which located on the top deck (superstructure). Gross tonnage which declared in tons, which is a volume unit of 100 (onehundred) cubic feet equivalent of 2,83 (two-point-eighty-three) cubic meters.

In calculating ship's Gross Tonnage (GT) based on Regulation of the Minister of Transportation Number: KM 6 Year 2005, Thus:

1. For the domestic measurements, which is the measurement for a ship that the length is less than 24 (twenty-four) meters, the contents of the rooms under the upper deck (deck measure) is a multiplicity of length, width and internal, multiplied by factors:

Contents of the room under the deck $=\mathrm{L} \times \mathrm{W} \times \mathrm{I} \times \mathrm{F}$

$\mathrm{L}=$ Ship's length, which is the horizontal distance from the rear of the ship stern

tall measured at the upper deck level or upper portion of the fixed ridge

$\mathrm{W}=$ Ship's width, which is the horizontal distance measured between the two

outer sides of the ship's hull in the largest place, excluding the bones.

I = Internal of the ship, which is the perpendicular distance in the largest place, measured from the underside of the base deck to the bottom of the deck or up to the altitude of the imaginary line across the upper side of the fixed hull.

$\mathrm{F}=$ Factor, determined by cross-sectional shape and / or net tonnage type (NT) is set at $30 \%$ of Gross Tonnage (GT).

2. For International calculations which intended for the ship that has a length of 24 (twenty-four) or more, used the formula shall be:

$\mathrm{GT}=\mathrm{K} 1 \times \mathrm{V}$

$\mathrm{K}_{1}=0.2+0.02 \log \mathrm{V}$

$\mathrm{V}=$ The number of rooms below the upper deck (deck measuring) and the contents of the rooms above the deck which perfectly closed that have a measurement of no less than $1 \mathrm{~m}^{3}$.

\section{Non-Migas (Oil and Gas) Exports to The Countries of Destination}

Exports are one of the most important and strategic economic activities. The increased in exports are expected to increase the revenues, labor and foreign exchange for the country. The 
Increased in exports are the main activities to generate foreign exchange to finance the development in riil and non-riil sectors. Indonesia's exports were initially dominated by oil and gas products (migas). Since 1974 to 1986, Indonesia's economic financing depended largely on oil and gas revenues. This situation caused Indonesia's economy to be very sensitive to changes of oil and gas prices in International markets.

Export activities will continue to occupy an important role as the activator of the domestic economy. Therefore, the direction of policy in the field of export trade is aimed to increase goods exports, especially non-migas (gas and oil) commodities. The non-migas (oil and gas) export commodities were chosen because of petroleum price deterioration in the world market. This resulted in decreasing of state revenues which came from oil and gas. To overcome the unfavorable situation, the government tried to reduce the dependency on oil and gas exports by diversifying the revenues towards production increasing and export increasing commodities and non-migas (oil and gas) services (Sukirno, 2002: 67).

\section{HYPOTHESIS}

$\mathrm{H}_{1}$ : General Cargo Cost has a significant effect on Non-Oil and Gas Exports

$\mathrm{H}_{1.1}$ : General Cargo Cost has a significant effect on Non-Oil and Gas Exports to U.S.A

$\mathrm{H}_{1.2}$ : General Cargo Cost has a significant effect on Non-Oil and Gas Exports to Japan

$\mathrm{H}_{1.3}$ : General Cargo Cost has a significant effect on Non-Oil and Gas Exports to Australia

$\mathrm{H}_{1.4}$ : General Cargo Cost has a significant effect on Non-Oil and Gas Exports to U.K

$\mathrm{H}_{2}$ : Unit ship's call has significant effect on Non-Oil and Gas Exports

$\mathrm{H}_{2.1}$ : Unit ship's call has significant effect on Non-Oil and Gas Exports to U.S.A

$\mathrm{H}_{2.2}$ : Unit ship's call has significant effect on Non-Oil and Gas Exports to Japan

$\mathrm{H}_{2.3}$ : Unit ship's call has significant effect on Non-Oil and Gas Exports to Australia

$\mathrm{H}_{2.4}$ : Unit ship's call has significant effect on Non-Oil and Gas Exports to U.K

$\mathrm{H}_{3}$ : Gross Tonnage Ship has a significant effect on Non-Oil and Gas Exports

$\mathrm{H}_{3.1}$ : Gross Tonnage Ship has a significant effect on Non-Oil and Gas Exports to U.S.A

$\mathrm{H}_{3.2}$ : Gross Tonnage Ship has a significant effect on Non-Oil and Gas Exports to Japan

$\mathrm{H}_{3.3}$ : Gross Tonnage Ship has a significant effect on Non-Oil and Gas Exports to Australia

$\mathrm{H}_{3.4}$ : Gross Tonnage Ship has a significant effect on Non-Oil and Gas Exports to U.K

$\mathrm{H}_{4}$ : Gross Tonnage Ship has a significant effect on Non-Oil and Gas Exports countries destination to U.S.A, Japan, Australia and U.K

\section{Type of research}

\section{RESEARCH METHODOLOGY AND DATA.}

This research is included in this type of causal research because the one variable with the other are related which is the independent variable and the dependent variable. According to Sugiyono (2014), the causal relation is a link that has characteristic of cause and effect, there are independent variables (variables that effect) and the dependent variable (affected). This research uses a quantitative approach, it is a research which uses research data in the form of numbers and analysis using a statistic (Sugiyono, 2014).

\section{Data collection technique}

The data obtained for this study came from secondary data obtained from review study and documentation. The review study is an analytical technique for obtaining information through notes, literature, etc. which still relevant, and documentation techniques are carried out by tracing and documenting the data and information related to the study object. 


\section{Data}

Tabel 1. Data of Stevedoring Loading Cost (Rp / Ton)

\begin{tabular}{|c|c|c|c|}
\hline \multirow{2}{*}{ Month } & \multicolumn{3}{|c|}{ Stevedoring (General Cargo) } \\
\cline { 2 - 4 } & $\mathbf{2 0 1 4}$ & $\mathbf{2 0 1 5}$ & $\mathbf{2 0 1 6}$ \\
\hline January & 41.287 & 45.287 & 54.837 \\
\hline February & 41.287 & 45.287 & 54.837 \\
\hline March & 41.287 & 45.287 & 54.837 \\
\hline April & 41.287 & 45.287 & 54.837 \\
\hline May & 41.287 & 45.287 & 54.837 \\
\hline June & 41.287 & 45.287 & 54.837 \\
\hline July & 41.287 & 45.287 & 54.837 \\
\hline August & 41.287 & 45.287 & 54.837 \\
\hline September & 41.287 & 45.287 & 54.837 \\
\hline October & 41.287 & 45.287 & 54.837 \\
\hline November & 41.287 & 45.287 & 54.837 \\
\hline December & 41.287 & 45.287 & 54.837 \\
\hline
\end{tabular}

Source : Port Authority of Surabaya period 2017

In Tabel 1.,the data of stevedoring rates that are rising in every year and the highest one in 2016 over the period from 2014 to 2016. These Stevedoring rates are a given provision from the Indonesian government, so there is no bargaining of costs in the market.

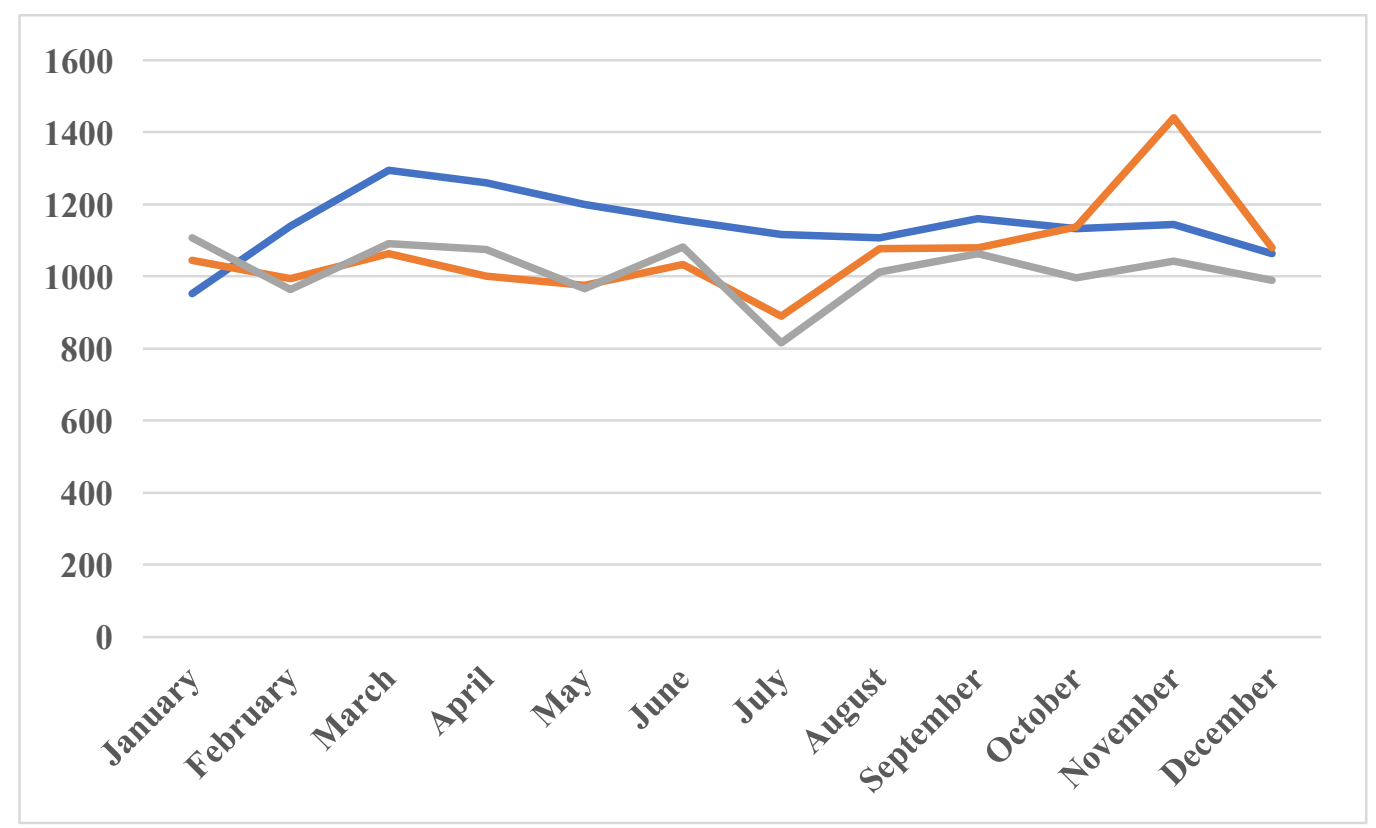

Source: Port Authority of Surabaya 2017

Unit Ship Call Year $2014 \quad$ Unit Ship Call Year $2015 \quad$ Unit Ship Call Year 2016

Figure 2. Unit ship's call (Unit/ Ship)

As can be seen in Figure 2, the increasing number of Unit ship's call in March and April on each year from 2014 to 2016. Ship's call shows the flow of ships entering a seaport within a certain time, and viewed from the economic aspect, thus, ship's call is a supply or offer of sea freight services. When the supply of sea freight services increases while the demand for sea freight services remains, then the freight or the cost of hawser per metric ton will decline. The freight rate of ships is ungiven, in other words, the rate of the hawser (freight ship) is created in the 
market by referring to the forces of supply and demand in the market (market forces).

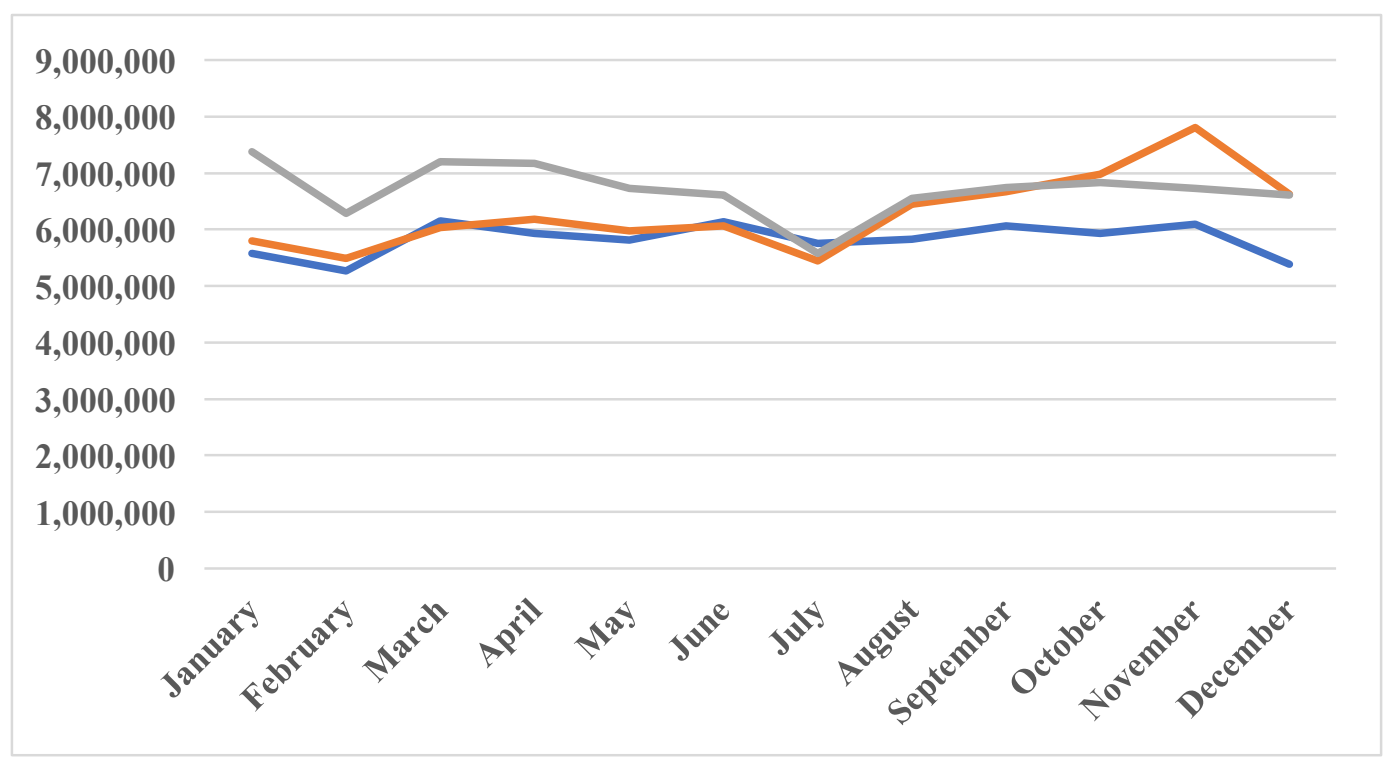

Source: Port Authority of Surabaya 2017

Year $2014 \longrightarrow$ Year $2015 \longrightarrow$ Year 2016

Figure 3. Ships's Gross Tonnage / GRT (Tonnage)

The graph in Figure 3. indicate that there is a tendency of up and down on gross tonnage from 2014 to 2016 in Surabaya port which peaked up significantly in 2015 but down again in 2016.

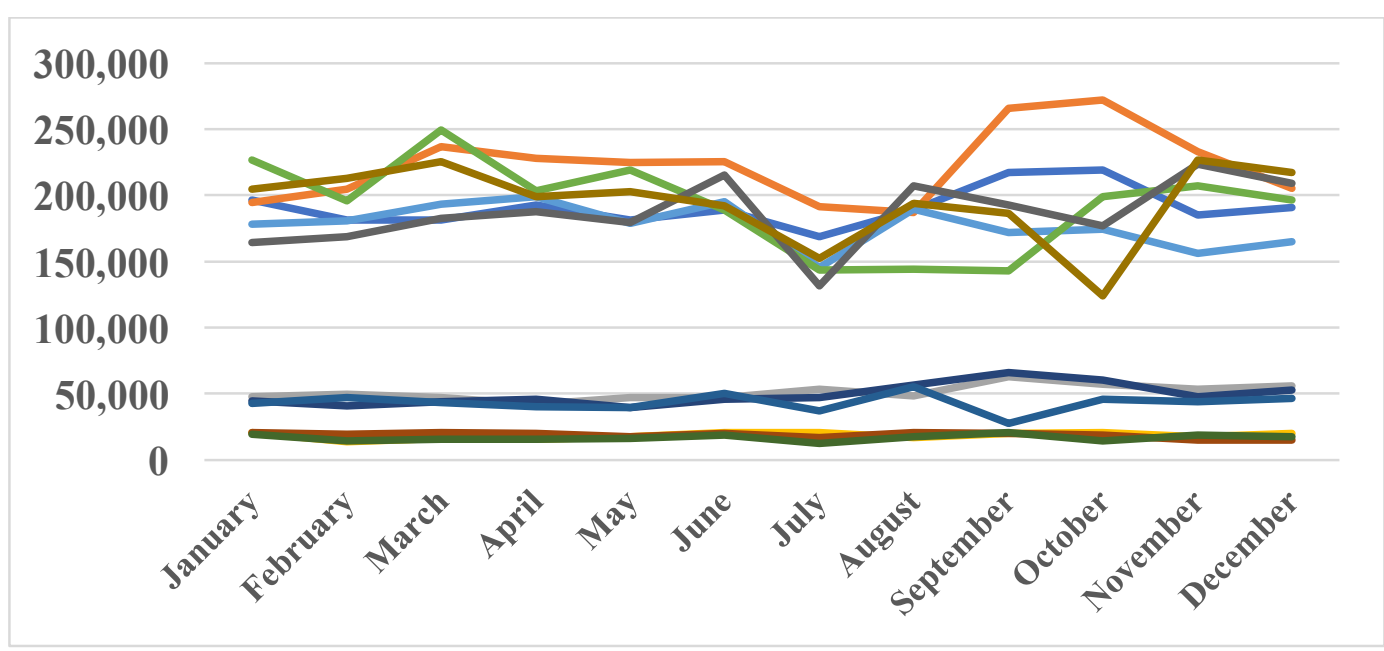

Source: Bank Indonesia 2017

$\begin{array}{lll}- \text { Year } 2014 \text { USA } & \text { Year } 2014 \text { Japan } & - \text { Year } 2014 \text { Australia } \\ \text { Year } 2014 \text { UK } & \text { Year } 2015 \text { USA } & - \text { Year } 2015 \text { Japan } \\ \text { Year } 2015 \text { Australia } & - \text { Year } 2015 \text { UK } & - \text { Year } 2016 \text { USA } \\ \text { Year } 2016 \text { Japan } & - \text { Year } 2016 \text { Australia } & - \text { Year } 2016 \text { UK }\end{array}$

Figure 4. Non-0il and gas Export Data Variable Towards the Destination Country (Thousands in US Dollar) 
As can be seen in in Figure 4., the export values from East Java to Australia, USA show a downward tendency, in contrast with exports to Japan and the U.K had significant increases in the period 2014-2016. The export values of East Java Province were the most significant in Australia from 2014 to 2016.

\subsection{Data analysis technique}

Data analysis is the process of simplifying the data into a form that is easier to be read and implemented. The chosen analysis technique for analyze the data and test the hypothesis in this research is The Structural Equation Model (SEM). To answer the hypothesis, it used Partial Least Square (PLS). According to Ghozali, (2012: 41) the calculations performed using Smart Partial Least Square (PLS) tool, due to the multi-lane shape and model used in the Reflective model. The calculation model is done by using Smart PLS tool because this research has multilane relationship and formative and reflective. Moreover, due to the sampling which were less than 100 respondents. Formative model is a model that shows relationship direction from indicator to latent variable. The reflective model is a model showing the relationship of the latent variable to the indicator.

The study also used multiple regression analysis to prove the influence of General Cargo, Unit Ships Call, Ship's Gross Tonnage towards Non-migas (oil and gas) Exports in U.S.A, Japan, Australia, and U.K respectively. Multiple linear regression analysis was used by the researcher, if the researcher intends to predict how the condition (the ups and downs) of the dependent variable (criterium), the value of two or more independent variables as the predictor factor will be manipulated (ascended or lowered in value) (Sugiyono, 2014). Besides, it also used different test of analysis to find out the differences of Non-migas (Oil and Gas) Exports between USA, Japan, Australia, and U.K.

\section{OPERATIONAL DEFINITION OF VARIABLES AND MEASUREMENT OF VARIABLES The Dependent Variable}

The dependent variable used in this research is Non-migas (Oil and Gas) Exports (Y). Nonmigas (oil and gas) export variable is measured using Non-migas (Oil and Gas) Exports data in USA, Japan, Australia and U.K from 2014 to 2016.

\section{Independent Variable}

The independent variables used in this research are:

1. Ship Loading Cost (General Cargo)

General Cargo or ship loading cost. In this study, the General Cargo is measured using the stevedoring tariff which is the job for unpacking goods from ship to dock/barge/ truck or loading goods from dock/barge/truck to ship until it is arranged in the hatch by using ships tow or land cranes. In this study, the data used stevedoring tariff at the Port of Surabaya-Indonesia from 2014-2016.

2. Unit Ships Call

Unit ship's call is a ship visit. By using data on the number of ship visits in Tanjung Perak Port Surabaya, Indonesia in 2014 - 2016.

3. Ship's Gross Tonnage

Ship's Gross Tonnage or gross tonnage which is the calculation of the volume of all the space located below the deck of the ship, plus the volume of enclosed space located above the deck plus the contents of the room and all the enclosed spaces located above the top deck. In this study, the ship's Gross Tonnage was obtained from gross tonnage data at Surabaya-Indonesia Port in 2014-2016. 


\section{Results of SEM Analysis with PLS program}

\section{RESULTS AND DISCUSSION}

The analysis of the suitability level of the constructed structural model reveal the conclusion that the overall model has been "Relevant" to explain the studied variables and the effects on each variables. The calculation of $\mathrm{Q}^{2}$ value, obtain the value of 0.436 or already exceeds the critical limit of 0.5 , thus, the structural model has been declared suifigure and appropriate.

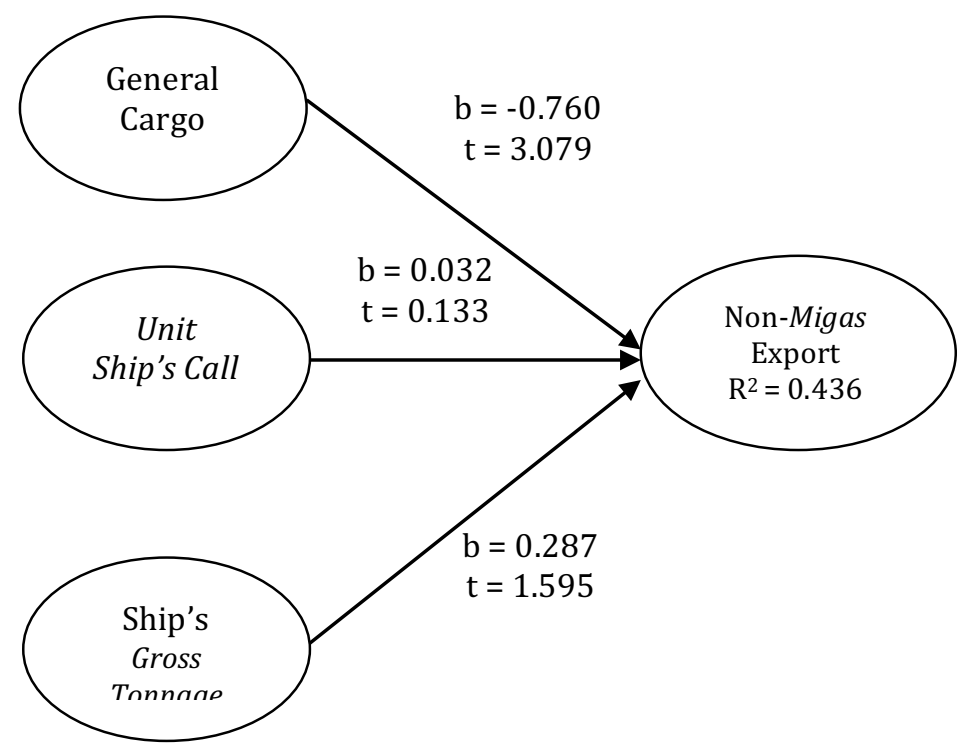

Figure 5. Inner PLS Model

There are 3 exogenous variables in the inner model, which are General Cargo, Unit Ships Call, Ship's Gross Tonnage, while the endogenous variable in the examined inner model is Non-migas (Oil and Gas) Exports. In the equation model with endogenous, Non-migas (Oil and Gas) exports the value of $\mathrm{R}^{2}$ reached 0.436. This means that Non-migas (Oil and Gas) Exports possible to be explained by General Cargo, Unit Ships Call, Ship's Gross Tonnage reach 43.6\%.

The result of $\mathrm{Q}^{2}$ was 0.436 which is in the range of $0.33-0.66$, so it can be said that the model is "Moderate" model.

\section{Results of Multiple Linear Regression Analysis}

Tabel 2. T test On Multiple Linear Regression Analysis

\begin{tabular}{|l|c|c|l|l|}
\hline \multirow{2}{*}{ Variabel } & \multicolumn{4}{|c|}{$\begin{array}{c}\text { Non-Migas (Oil and Gas) Countries } \\
\text { Destination (Y) Exports }\end{array}$} \\
\cline { 2 - 5 } & $\begin{array}{c}\text { U.S.A } \\
(\mathrm{Y} 1)\end{array}$ & $\begin{array}{c}\text { Japan } \\
(\mathrm{Y} 2)\end{array}$ & $\begin{array}{c}\text { Australia } \\
(\mathrm{Y} 3)\end{array}$ & $\begin{array}{c}\text { England } \\
(\mathrm{Y} 4)\end{array}$ \\
\hline Ship Loading Cost (General Cargo) (X1) & 0.516 & 0.489 & $0.004^{* *}$ & $0.038^{* *}$ \\
\hline Unit ship's call (X2) & 0.333 & $0.022^{* *}$ & 0.217 & 0.148 \\
\hline Ship's Gross Tonnage (X3) & 0.525 & 0.196 & 0.054 & 0.192 \\
\hline
\end{tabular}

Based on the results of multiple linear regression analysis, it showed that all independent variables consist of General Cargo, Unit Ships Call, Ship's Gross Tonnage has no significant effect on Non-migas (Oil and Gas) Exports of U.S.A Destination Country. In Non-migas (Oil and Gas) Export Destination to Japan is only Unit ship's call variable which known to has a significant effect. Then, it can also be explained that only the General Cargo variable has a significant effect on the Non-Oil and Gas Exports of Australian Destination Countries. Similarly to the Non-Oil 
and Gas Exports of the U.K as Destination Countries, it is known that only the General Cargo variable has a significant effect.

\section{Comparative Test Results}

Tabel 3. Comparative Test

\begin{tabular}{|l|l|l|l|}
\hline Levene Statistic & df1 & df2 & Sig \\
\hline 19.249 & 3 & 140 & 0.000 \\
\hline
\end{tabular}

The comparative test results show a sig value of 0,000 which means less than 0.05 so it can be explained that there are differences in non-migas (oil and gas) exports between the destination countries (U.S.A, Japan, Australia, and U.K).

\section{Hypothesis Test Results \\ Hypothesis Test 1}

The first hypothesis in the research proved the validity, because the results of data analysis showed that the value of $t$ equal to 3,079 which means greater than 1.96 , so it can be said that the ship loading cost (General Cargo) has a significant influence on Non-migas (Oil and Gas) Exports with a big influence of 0.760 with negative direction which means the higher Ship loading cost (General Cargo) or the loading cost, thus, the lower non-migas (oil and gas) exports activities conducted.

The results from multiple linear regression analysis shows that the hypothesis $\mathrm{H}_{1.1}$ and $\mathrm{H}_{1.2}$ is not proven the validity because the significant value shows greater than 0.05 , so, the independent variable of General Cargo has no significant effect on Non-migas (Oil and Gas) Export of U.S.A and Japan as Destination Country, while the hypothesis $\mathrm{H}_{1.3}$ and $\mathrm{H}_{1.4}$ proved to be valid because the significant value showed smaller than 0.05 , thus, that the independent variable of General Cargo has a significant effect on Non-migas (Oil and Gas) Exports of Australian and U.K Destination Countries.

\section{Hypothesis 2}

The second hypothesis in the study is not proven, because the result of data analysis shows that the thave value of 0.133 which means smaller than 1.96 , so it can be said that Unit ship's call has no significant effect on Non Oil and Gas exports with substantial influence of 0.032 which means the increasing arrival rate of ship at the Surabaya-Indonesia port will not guarantee the increase of Non Oil and Gas Exports activities.

The results of multiple linear regression analysis showed that hypothesis $\mathrm{H}_{2.1}, \mathrm{H}_{2.3}$ and $\mathrm{H}_{2.4}$ not proven the validity, because significant value shows bigger than 0,05 , so that the independent variable of Unit ship's call has no significant influence on Non-Oil and Gas Export to U.S.A, Australia, and the U.K, while the hypothesis H2.2 proved to be valid because the significant value indicates smaller than 0.05 , thus, the independent variable of Unit ship's call has significant influences on Non-Oil and Gas Export of Destination Country to Japan.

\section{Hypothesis 3}

The third hypothesis in the research is not proven, due to the results of data analysis shows that the value of $t$ is 1.595 which means smaller than 1.96, so it can be said that Gross Tonnage has no significant effect to Non Oil and Gas Exports with a substantial influence of 0.287 which means the higher gross tonnage not necessarily will be able to increase the activity of Non Oil and Gas Exports. 
Sembiring, M. J., \& Sasono, H. B. (2018). The Effects Of Ship Loading Cost (General Cargo), Unit Ship's Call And Ship's Gross Tonnage Towards NonMigas (Oil And Gas) Exports, With Four Destination Countries To U.S.A, Japan, Australia, And United Kingdom At Port Of Surabaya, Indonesia In 2014-2016. Archives of Business Research, 6(4), 224-236.

The results of multiple linear regression analysis showed that hypothesis $\mathrm{H}_{3.1}, \mathrm{H}_{3.2}, \mathrm{H}_{3.3}$ and $\mathrm{H}_{3.4}$ not proven to be valid because significant value shows greater than 0,05 , so that independent variable of Ship's Gross Tonnage has no significant effect towards Exports of Non Oil and Gas of the Destination Countries (USA, Japan, Australia, and U.K).

\section{Hypothesis 4}

The fourth hypothesis in the research proved to be valid because the results of data analysis showed that the sig has a value of 0.000 which means smaller than 0.05 , so it can be said that there are differences in non oil and gas exports between the destination countries to USA, Japan, Australia, and U.K.

\section{DISCUSSION}

Based on the result of data analysis, it can be seen that the General Cargo or ship loading cost which measured by using stevedoring tariff has significant influence to non oil and gas export which shown with $t$ value equal to 3,079 which means more than 1.96 . The influences of these two variables shows negative direction of 0.760 , which means that the lower cost of ships will increase the non-oil and gas export activities. On the contrary, the higher ship loading costs, it will possibly to decrease the non-oil and gas export activities. This is because of high costs in dollar exchange rate result in limitation of non oil and gas export activities due to the uncertainty of export activity able to generate feedback or impact on economic growth of Indonesia. Besides, the expensive goods loading cost will increase the operational costs incurred in the cost of ship loading cost, thus, to reduce non-oil and gas export activities are more preferable. However, based on the results of multiple regression analysis, it shows that the ships loading cost (general cargo) only has a significant effect on non-oil and gas exports of the destination countries to Australia and England, while the non-oil and gas exports of destination countries to USA and Japan has no significant effect.

The analysis result also found unit ship's call or ship visit have no significant effect on non oil and gas exports. This indicates that high rates of ship visits will not limit the conducted non-oil and gas exports activities, and the direction of the connection between these two variables is positive, which means the more ship visits conducted, then, the more non-oil and gas export activities will increase. However, units ship's call show significant effect on non-oil and gas exports to Japan, while non-oil and gas exports of U.S.A, Australia and U.K destinations are not significant.

Similar with Gross Tonnage Ship or gross tonnage which has no significant effect on non-oil and gas exports. This shows, that gross tonnage will not limit the conducted non-oil and gas export activities, and the direction of the connection between the two variables is positive, which means the more gross tonage conducted, then, the more non-oil and gas export activities will decrease, meanwhile, the less gross tonnage conducted, the more export activity of non-oil and gas will increase. Regression analysis results also show that Ship's Gross Tonnage has no significant effect on non-oil and exports of destinations to U.S.A, Japan, Australia and U.K. Based on the results of different test analysis, it shows that there are differences in non-oil and gas exports between destination countries to U.S.A, Japan, Australia, and the U.K.

\section{Conclusion}

\section{CONCLUSIONS AND SUGGESTIONS}

1. General Cargo or ship loading costs had a significant effect on the negative direction of the non-oil and gas exports to Europe countries destination in the Surabaya-Indonesia 
Port in 2014-2016. However, the General Cargo or ship loading costs only have a significant effect on the Non-Oil and Gas Exports to Australia and U.K.

2. There was no significant influence on the positive direction of unit ship's call or ship visits to non-oil and gas exports of Europe countries destinations in the SurabayaIndonesia Port in 2014-2016. However, the results of Unit ship's call only have a significant effect on Japan's Non-Oil and gas Exports Destination.

3. There was no significant influence on the positive direction of Gross Tonnage Ship or gross tonnage of Non-Oil and gas Exports destination to European Countries in the Port of Surabaya-Indonesia in 2014-2016. Similar with multiple regression analysis results which indicate if Gross Tonnage Ship or gross tonnage had no significant effect on NonOil and Gas Export to U.S.A, Japan, Australia, and U.K.

4. Different test analysis results showed that there were differences in non-oil and gas exports between destination countries to U.S.A, Japan, Australia, and U.K.

\section{Suggestion}

1. It is expected, that, the costs will not be too high in order to attract more investors to active in exporting non-oil and gas goods that can be taken from the state treasury or the local treasury to trigger the investors to be more productive in selling overseas.

2. It is expected, that, in the future this research will be able to use other research objects other than in Surabaya-Indonesia Port and can also add a longer study period in order to obtain more complex results.

\section{References}

Bendall, H. B., \& Stent, A. F. (2001). A scheduling model for a high speed containership service: A hub and spoke short-sea application. International Journal of Maritime Economics, 3(3), 262-277.

Blonigen, B. A., \& Wilson, W. W. (2008). Port efficiency and trade flows. Review of International Economics, 16(1), 21-36.

Cullinane, K., \&Khanna, M. (2000). Economies of scale in large containerships: optimal size and geographical implications. Journal of transport geography, 8(3), 181-195.

Dwyer, L., Douglas, N., \&Livaic, Z. (2004). Estimating the economic contribution of a cruise ship visit. Tourism in marine environments, $1(1), 5-16$.

Gardner, B., Marlow, P., \& Pettit, S. (2006). Full cost recovery in EU ports operating as commercial undertakings. Transport Policy, 13(1), 2-21.

Ghozali, Imam. 2012. Aplikasi Analisis Multivariate dengan Program IBM SPSS. Yogyakarta: Universitas Diponegoro

Herman Budi Sasono (2017), Manajemen Eksport dan Perdagangan Internasional. Publisher: Andi

Kozan, E. (2000). Optimising container transfers at multimodal terminals. Mathematical and Computer Modelling, 31(10-12), 235-243.

Mangan, J., Lalwani, C., \& Fynes, B. (2008). Port-centric logistics. The International Journal of Logistics Management, 19(1), 29-41.

Millerd, F. (2011). The potential impact of climate change on Great Lakes international shipping. Climatic Change, 104(3-4), 629-652.

Parlindungan Manik, Deddy Chrismianto, Gigih Niagara (2013), Perancangan Kapal General Cargo 1500 DWT Rute Pelayaran Jakarta-Surabaya. KAPAL- Vol. 10, No.2 June 2013:108

Park, C. S., \& Noh, Y. D. (1987).A port simulation model for bulk cargo operations. Simulation, 48(6), $236-246$.

Parola, F., \&Sciomachen, A. (2005). Intermodal container flows in a port system network: Analysis of possible growths via simulation models. International journal of production economics, 97(1), 75-88.

Sánchez, R. J., Hoffmann, J., Micco, A., Pizzolitto, G. V., Sgut, M., \&Wilmsmeier, G. (2003). Port efficiency and international trade: port efficiency as a determinant of maritime transport costs. Maritime economics \& logistics, 5(2), 199-218. 
Sembiring, M. J., \& Sasono, H. B. (2018). The Effects Of Ship Loading Cost (General Cargo), Unit Ship's Call And Ship's Gross Tonnage Towards NonMigas (Oil And Gas) Exports, With Four Destination Countries To U.S.A, Japan, Australia, And United Kingdom At Port Of Surabaya, Indonesia In 2014-2016. Archives of Business Research, 6(4), 224-236.

Stonham, P. E. (1969). USER COSTS IN PORT: AN AUSTRALIAN STUDY1. Australian Economic Papers, 8(13), 178192.

Sugiyono. 2014. Metode Penelitian Pendidikan Pendekatan Kuantitatif, Kualitatif Dan R\&D. Bandung: Alfabeta. Sukirno, Sadono, 2002, "Pengantar Teori Makro ekonomi”, Cetakan keempat belas, Publisher: PT Raja Grafindo persada.

Suyono ( 2005). Shipping: Pengangkutan Intermodal Ekspor Impor Melalui Laut (Edisi 4)

Todaro, Michael P (2000), Theories of development; Economic Development: Developing Countries-Economic Policy; Trade Theory; Structural-Change Models; Poverty; Unemployment; Agricultural Development; New Growth Theory. Publisher: Addison-Wesley

Tongzon, J. L. (2009). Port choice and freight forwarders. Transportation Research Part E: Logistics and Transportation Review, 45(1), 186-195.

Vacca, I., Bierlaire, M., \& Salani, M. (2007). Optimization at Container Terminals: Status, Trends and Perspectives. In Swiss Transport Research Conference (No.TRANSP-OR-CONF-2006-013).

Yu, M. M., Hsiao, B., Hsu, S. H., \& Li, S. Y. (2012). Measuring harbor management, stevedoring and warehousing performance of Taiwanese container ports using the multi-activity network DEA model. Journal of international logistics and trade, 10(2), 77. 